\title{
Öğretmen Adaylarının Sosyal Ağ Sitelerini Kullanma Durumlarına Göre Sosyal Anlatımcılık Beceri Düzeylerinin İncelenmesi
}

\author{
Dr. Öğr. Üyesi Nesrin Hark Söylemez ${ }^{1 *}$ \\ Prof. Dr. Behçet Oral ${ }^{2}$
}

Geliş tarihi: 26.09 .2019

Kabul tarihi: 06.11.2019

\section{Atuf bilgisi: \\ IBAD Sosyal Bilimler Dergisi \\ Sayı: $5 \quad$ Sayfa: $343-358$ \\ Yıl: 2019 Dönem: Güz}

This article was checked by iThenticate.

1Dicle Üniversitesi, Türkiye, nesrin_hark@hotmail.com ORCID ID 0000-0002-6306-5595

2Dicle Üniversitesi, oralbehcet@yahoo.com , ORCID ID 0000-0002-6885-1683

\footnotetext{
* Sorumlu Yazar
}

$\ddot{O} \mathbf{Z}$

$\mathrm{Bu}$ çalışma öğretmen adaylarının sosyal ağ sitelerini kullanım durumlarına göre sosyal anlatımcılık beceri düzeylerini incelemeyi amaçlamaktadır. Bu amaca uygun olarak araştırmada tarama modeli kullanılmıştır. Çalışmanın örneklemini 2012-2013 eğitim-öğretim yılı bahar yarıyılında bir devlet üniversitesinde lisans programına devam eden 701 öğretmen adayı oluşturmaktadır. Çalışmada, sosyal ağ sitelerinin kullanımıyla ilgili veriler araștırmacı tarafindan geliștirilen "Sosyal A $\breve{g}$ Siteleri Kullanım Ölçeği" ile elde edilmiş; sosyal beceri düzeyleri ise Riggio tarafindan 1989 yılında geliştirilen ve Türkçeye uyarlaması 2004 yılında Galip Yüksel tarafindan yapılan "Sosyal Beceri Envanteri" ile değerlendirilmiştir. Araştırmanın verileri, parametrik testlerin varsayımlarını yerine getirmediğinden, verilerin analizinde Mann- Whitney U testi ve Kruskal Wallis Varyans Analizi kullanılmıştır. Kruskal Wallis varyans analizi sonucunda anlamlı fark bulunduğu takdirde farkın hangi gruplar arasında olduğunu belirlemek için Bonferroni düzeltmeli Mann Whitney U testi kullanılmıştır. Çalışmanın sonuçlarına göre öğretmen adaylarının sosyal anlatımcılık beceri düzeyleri; sosyal ağlara üye olma durumlarına, sosyal ağ sitelerine üye oldukları süreye, aktif olarak kullandıkları sosyal ağ sayısına, sosyal ağ sitelerinde bir günde ortalama geçirdikleri süreye, sosyal ağ sitelerinde yer alan içeriklere yorum yazma durumlarına, sosyal ağ sitelerindeki yazıșmalarında yüz simgelerini kullanma durumlarına göre anlamlı bir farklılık göstermektedir. Ancak öğretmen adaylarının sosyal anlatımcılık beceri düzeyleri, sosyal ağları en fazla kullanma amaçlarına göre anlamlı bir farklılık göstermemektedir. Elde edilen sonuçlara dayalı olarak öneriler sunulmuştur.

Anahtar Kelimeler: Sosyal Ağ Siteleri, Sosyal Beceri, Sosyal Anlatımcılık Becerisi, Öğretmen Adayları 


\title{
An Investigation of Candidate Teachers' Social Expressivity Skill Levels according to Their Use of Social Network Sites
}

\author{
Assist. Prof. Dr. Nesrin Hark Söylemez ${ }^{1^{*}}$ \\ Prof. Dr. Behçet Oral ${ }^{2}$
}

First received: 26.09 .2019

Accepted: 06.11.2019

\section{Citation:}

IBAD Journal of Social Sciences

Issue: 5

Pages: $343-358$

Year: 2019

Session: Fall

This article was checked by iThenticate.

1Dicle University, Turkey, nesrin_hark@hotmail.com ORCID ID 0000-0002-6306-5595

2Dicle University, Turkey,

\begin{abstract}
This study is intended to researche candidate teachers' social expressivity skill levels according to their use of social network sites. Survey method is used based on this purpose. Sample of the study is composed of 701 candidate teachers studying at a state university, Faculty of Education in Spring semester of 2012 - 2013 academic year. The data on the usage of social networking sites is collected through the "Social Network Sites Usage Survey" developed by the researcher and the social skills levels were assesed through "Social Skills Inventory", developed by Riggio in 1989 and translated into Turkish by Galip Yüksel in 2004. As the data of the research doesn't meet the hypothesis of the parametric tests, Mann - Whitney U test and Kruskal Wallis Variance Analysis have been used for data analysis. In case of detection of a significant difference as a result of Kruskal Wallis variance analysis, Mann Whitney U test, adjusted by Bonferroni, was used in order to determine the groups between which difference is significant. According to the results of the study, Social expressivity skill levels of teacher candidates showed significant difference with respect to their membership of social network sites, the duration of their membership to social network sites, the average of daily time spent on social network sites, their making comments on contents in social network sites, their main purpose of using social network sites and their use of smileys in social network sites.. However, no significant difference detected among total social skill levels with respect to their main purpose of using social network sites. Suggestions were made based upon the obtained results.
\end{abstract}

oralbehcet@yahoo.com

ORCID ID 0000-0002-6885-1683

Anahtar Kelimeler: Social Network Sites, Social Skills, Social Expressivity Skill, Teacher Candidates

\footnotetext{
* Corresponding Author
} 


\section{GíRiș}

Günümüzde internet, yeni bir sosyal etkileşim ortamı sağlamakta, yeni toplumsal ilişki biçimlerinin gelişmesine aracilık etmekte, bireylerin sosyalleşme ve sosyal iletişime geçme şeklini değişime uğratmaktadır. İnternet, önceleri sadece kişisel iletişime imkân tanırken artık bireylerin sosyalleştiği ve sosyal paylaşımlarda bulunduğu bir alan haline gelmiştir. Bu değişimin en önemli nedenlerinden biri de geliştirilen ve yaygınlaşan sosyal ağ siteleridir (Göker, Demir ve Doğan, 2010, s. 184).

Sosyal ağlar, ortak bir amaç doğrultusunda insanların düşüncelerini paylaşmalarını ve birbirleriyle etkileşime girmelerini kolaylaştıran internet üzerinden bir topluluk oluşumunu işaret etmektedir (Preeti, 2009, s. 129). Sosyal ağ siteleri (Facebook, MySpace, Friendster vb.); kullanıcıların, kullanıcı adı ve fotoğraf gibi profil bilgileri göndermelerine, genel/özel çevrimiçi mesaj gönderimine veya çevrimiçi fotoğraf, video paylaşımı gibi yenilikçi yollar kullanarak diğer bireylerle iletişim kurmalarına izin veren üye tabanlı internet topluluklarıdır (Pempek, Yermolayeva ve Calvert, 2009, s. 227).

Bireylerin iletişim kurma ve sosyal çevre oluşturma alışkanlıklarının şekillenmesinde şüphesiz ki en önemli pay sosyal ağ sitelerinindir (Erkoç ve Erkoç, 2011). Sosyal ağlar, bireylerin birbirleri ile bağlantı kurmak amacıyla en çok tercih ettikleri iletişim ortamı olarak yaygınlaşmaktadır (Çetin, 2009). Her gün bilgisayarını açar açmaz profilini ve sosyal ağ sitelerindeki mesajlarını kontrol eden kişilerin sayısı on binler ile ifade edilmektedir (Acun, 2009, s. 365). Ülkemizde, TÜİK Hane Halkı Bilişi̇im Teknolojileri Kullanım Araştırması (2016) sonuçlarına göre bilgisayar ve internet kullanım oranının en yüksek olduğu yaş grubu 16-24 yaş aralığındaki genç gruptur.

Sosyal ağ sitelerinin doğru kullanılması durumunda pek çok faydası bulunmaktadır. Bu siteler sayesinde bireylerin istedikleri an pek çok farklı konu hakkında değişik bilgilere ulaşabilme, eski arkadaşları tekrar bulabilme, yeni arkadaşlıklar edinme, gruplar kurma ve gruplara dâhil olma, oyun oynama, eğlenme, bir yeniliği ya da yeni bir fikri duyurma imkânları bulunmaktadır (Baysal, 2010, s. 133). Günümüz toplumunun hızlı yaşanan kopuk ilişkileri içerisinde sosyal paylaşım ağları yardımıyla insanlar bir sosyal iliş̧i kurma ya da mevcut olan ilişkilerini sürdürme şansına sahip olabilmektedirler. Sosyal paylaşım ağları bireyleri, toplumun gittiği yönde sosyal olarak tamamlayan bir bileşen olarak karşımıza çıkmaktadır (Özmen vd., 2011, s. 45-46). Doğru kullanılmaması halinde ise, sosyalleşmeyi artırmanın aksine sosyal hayattan uzaklaştırmaya ve verilen kişisel bilgiler nedeniyle güvenliğin tehlikeye atılmasina sebep olabilmektedir (Baysal, 2010, s. 133).

Teknolojik gelişmelerin hızı, insan yaşamını gerek kültürel gerekse sosyal yönden etkilemektedir. $\mathrm{Bu}$ gelişmelerle ortaya çıkan sosyal ağ siteleri; sosyal yönden bireyleri bir araya getirme, yeni arkadaşlar edinme ve ikili ya da çoklu ilişkiler kurma gibi olanaklarıyla yeni topluluklar yaratmaktadır. $\mathrm{Bu}$ toplulukların, normal yaşamdaki topluluklardan farklı özelliklere sahip olduğu, farklı kültürel ve sosyal ilişkiler kurulduğu ve bireylerin sosyal becerilerini değiş̧irdiği söylenebilir (Sarsar, 2008, s.26). Bu açıklamalardan yola çıkarak sosyal becerilerin yeni teknolojik yapılanmalardan ve bunların fazla kullanılmasından etkilendiği ifade edilebilir.

Combs ve Slaby (1977) (Akt: Deniz, 2002, s. 62) sosyal becerileri, başkalarıla toplumsal olarak kabul edilebilir, kişisel olarak yararlı ve aynı zamanda öncelikle başkalarına yararlı olan sosyal bağlamda etkileşim kurma yeteneği şeklinde tanımlamışlardır. Dowrick (1986) (Akt: Seven ve Yoldaş, 2007, s. 3)'e göre sosyal beceriler, belli bir ortamda toplumsal olarak kabul görecek, hem kişinin kendisi hem de karşısındaki için yararlı olacak şekilde davranabilme becerisidir.

Riggio (1986) sosyal becerileri altı alt boyutta açıklamıştır. Riggio tarafından geliştirilen sosyal beceri envanteri, sosyal iletişim becerilerini duyuşsal ve sosyal olmak üzere iki seviyede ölçen altı alt ölçeği kapsar; "anlatımcılık", "duyarlılık", "kontrol" her bir seviye ile değerlendirilmektedir. Anlatımcılık bireylerin birbirlerine mesaj gönderme becerisini ifade etmektedir. Sosyal anlatımcillk (social expressivity) ise bireylerin birbirleriyle sosyal iletişim kurma ve iletişime katılma becerilerini ifade etmektedir. Bu beceri düzeyi yüksek olan bireyler başkalarıyla konuşmaya başlama becerileri sayesinde toplulukça sevilirler ve sempatik görünürler. Özellikle sosyal kontrol alt ölçeği puanı düşük olan bireyler, sosyal anlatımcı bireylerdir. Bu bireyler söylemek istediklerini içeriğe bağlı olmaksızın kendi başlarına konuşmayı kolaylıkla yönlendirebilirler. Diğer bir deyişle sosyal anlatımcı bireyler spontane 
bir şekilde konuşmayı sürdürebilirler. Ayrıca sempatik, kayıtsız, atılgan ve gruba bağımlıdırlar (Akt: Yüksel, 2004).

İletişim kurmak, yeni arkadaşlar ve çevreler edinmek için kullanılan sosyal ağ sitelerinin kişilerin sosyal becerilerini olumlu ya da olumsuz olarak nasıl etkilediği hâlâ belirsizdir. Toplumun her kesiminde görev alan bireylerin sosyal becerilere sahip olması oldukça önemlidir. Ancak bazı meslek grupları için sosyal becerilere sahip olma ihtiyacı kaçınılmazdır. Bu meslek gruplarından biri ise öğretmenlik mesleğidir. Çünkü sınıfta öğretmen ile öğrenci arasındaki ilişkiler, öğrenmenin ve eğitimin temelini oluşturur ve öğrenmeyi olumlu yönde etkiler. $\mathrm{Bu}$ doğrultuda eğitim ve öğretimin kalitesini artırmak için öğretmenlerin olumlu iletişimde gerekli olan sosyal becerilere de sahip olması beklenmektedir. $\mathrm{Bu}$ nedenlerle yapılan araştırmada, öğretmen adaylarının, hayatımızda oldukça önemli bir yere ve gün geçtikçe artan kullanım oranlarına sahip olan sosyal ağ sitelerini kullanma durumlarına göre sosyal anlatımcılık beceri düzeylerinin incelenmesi amaçlanmıştır.

\section{Araştırmanın Amacı}

Araştırmanın amacı, öğretmen adaylarının sosyal ağ sitelerini kullanma durumlarına göre sosyal anlatımcılık beceri düzeylerini incelemektir. Bu amaç doğrultusunda aşağıdaki sorulara cevap aranmıştır:

Öğretmen adaylarının Sosyal Anlatımcılık Becerilerine ilişkin puanları arasında;

a. Sosyal ăg sitelerine üye olma durumlarına,

b. Sosyal ağ sitelerine üye oldukları süreye,

c. Aktif olarak kullandıkları sosyal ağ sayısına,

d. Sosyal ăg sitelerinde bir günde ortalama geçirdikleri süreye,

e. Sosyal ağları en fazla kullanma amaçlarına,

f. Sosyal ağ sitelerinde yer alan içeriklere yorum yazma durumlarına,

g. Sosyal ağ sitelerindeki yazışmalarında yüz simgelerini kullanma durumlarına, göre istatistiksel olarak anlamlı fark var midır?

\section{YÖNTEM}

$\mathrm{Bu}$ bölümde, araştırma modeline, araştırmanın evren ve örneklemine, veri toplama araçlarına, veri toplama sürecine ve verilerin çözümlenmesine yer verilmiştir.

\subsection{Araştırmanın Modeli}

Öğretmen adaylarının sosyal ăg sitelerini kullanma durumlarına göre sosyal beceri düzeylerini belirlemek amacıyla yapılan bu araştırmada nedensel karşılaştırma deseni kullanılmıştır. Bu tür araştırmalarda, gruplar arasındaki farklılıkların nedenleri ve sonuçları katılımcılara ve koşullara herhangi bir müdahale yapılmaksızın belirlenir (Büyüköztürk vd., 2013). Nedensel karşılaştırma yöntemi kritik bir değişkende farklllık gösteren, ancak karşılaştırılabilir olan örneklemlerin karşılaştırılmasını içerir. Değişkenler arası neden sonuç ilişkisini araştıran bir yaklaşımdır. Kategorik gruplar arası ilişki bu yöntemle daha kolay yorumlanabilir (Borg ve Gall, 1989; Akt. Balc1, 2009).

\subsection{Evren ve Örneklem}

Bu araştırmanın çalışma evrenini 2012-2013 eğitim-öğretim yılı bahar yarıyılında Dicle Üniversitesi, Ziya Gökalp Eğitim Fakültesine bağlı Ortaöğretim Fen ve Matematik Alanlar Eğitimi ve Ortaöğretim Sosyal Alanlar Eğitimi Bölümlerinde öğrenim görmekte olan 4. ve 5. sınıf, Türkçe Eğitimi, Yabancı Diller Eğitimi ve Güzel Sanatlar Eğitimi Bölümlerinde öğrenim görmekte olan 3. ve 4. sınıf öğrencileri oluşturmaktadır. Araştırmada çalışma evreninin tamamına ulaşılması hedeflendiğinden örneklem seçimine gidilmemiştir. Ancak veri toplama araçlarının uygulandığı gün derse gelmeyen öğrencilerin olması ve bir kısım veri toplama aracının geçersiz olmasından dolayı çalışma evrenini oluşturan toplam 996 öğretmen adayı içerisinden 701 öğretmen adayına ulaşılmış, bu durumda araştırmaya katılanların 
çalışma evrenini örnekleme oranı \%70,4 olarak hesaplanmıştır. Araştırmaya katılan öğretmen adaylarının özellikleri aşağıdaki tablolarda verilmiştir.

Tablo 1. Araştırmaya Katılan Öğretmen Adaylarının Cinsiyetlerine Göre Dă̆glımı

\begin{tabular}{|c|c|c|}
\hline Cinsiyet & F & \% \\
\hline Kadın & 374 & 53,4 \\
\hline Erkek & 327 & 46,6 \\
\hline Toplam & 701 & 100 \\
\hline
\end{tabular}

Tablo 1'de görüldüğü gibi araştırmaya katılan 701 öğretmen adayının \%53,4'ü (374 kişi) kadın, $\% 46,6$ 's1 (327) erkektir.

Tablo 2. Araştırmaya Katılan Öğretmen Adaylarının Bölümlerine Göre Dağılımı

\begin{tabular}{|l|c|c|}
\multicolumn{1}{|c|}{ Bölüm } & F & \% \\
\hline Ortaöğretim Fen ve Matematik Alanlar Eğitimi & 171 & 24,4 \\
\hline Ortaöğretim Sosyal Alanlar Eğitimi & 134 & 19,1 \\
\hline Yabancı Diller Eğitimi & 133 & 19,0 \\
\hline Güzel Sanatlar Eğitimi & 90 & 12,8 \\
\hline Türkçe Eğitimi Bölümü & 173 & 24,7 \\
\hline Toplam & 701 & 100 \\
\hline
\end{tabular}

Tablo 2'de görüldüğü gibi araştırmaya katılan 701 öğretmen adayının \%24,4’ü (171 kişi) Ortaöğretim Fen ve Matematik Alanlar Eğitimine, \%19,1'i (134 kişi) Ortaöğretim Sosyal Alanlar Eğitimine, \% 19'u (133 kişi) Yabancı Diller Eğitimine, \%12,8’i (90 kişi) Güzel Sanatlar Eğitimine, \%24,7'si (173 kişi) Türkçe Eğitimi Bölümüne devam etmektedir.

Avrupa Çevrimiçi Çocuklar Projesi III (EU Kids Online III) raporu verilerine göre; sosyal ağ üyeliği 13 yaş sınırı gerektirmektedir. Bu nedenle araştırmada sınıf içi etkinliklerde sosyal ağ sitelerini kullanmaları uygun olmayan ilköğretim bölümü öğretmen adaylarına yer verilmemiş̦ir.

\subsection{Veri Toplama Araçları}

\subsubsection{Sosyal Ă̆ Siteleri Kullanım Ölçeği}

Öğretmen adaylarının sosyal ağ sitelerini kullanım durumlarını belirlemek amacıyla araştırmacı tarafından oluşturulan 11 soruluk bir ölçeği kullanılmıştır. Ölçeği ilk kısmında öğretmen adaylarının demografik özelliklerine (öğrenim görülen bölüm, sınıf, cinsiyet, yaş) sonraki kısımda ise sosyal ağ sitelerini kullanım durumlarına (aktif olarak kullanılan sosyal ağ sayısı, sosyal ağ sitelerini kullanma süreleri ve kullanma amaçları v.b.) yönelik sorular yer almaktadır.

Sosyal Ağ Siteleri Kullanım Anketinde yer alacak maddelerin belirlenmesi sürecinde hem alanyazında yer alan benzer ölçekler incelenmiş hem de uzman görüşlerine başvurulmuştur. Sosyal A $\breve{g}$ Siteleri Kullanım Ölçeği hazırlanırken alınan uzman görüşleri, ölçeğin kapsam geçerliliği için yeterli bulunmuştur.

\subsubsection{Sosyal Beceri Envanteri}

Araştırmada öğretmen adaylarının sosyal beceri düzeylerini ölçmede Sosyal Beceri Envanteri (SBE) kullanılmıştır. Sosyal Beceri Envanteri "Social Skills Inventory", 1986 yılında Riggio tarafindan geliştirilmiş ve 1989 yılında yeniden revize edilerek bugünkü şeklini almıştır. Envanterin Türkçe'ye 
uyarlaması Yüksel (2004) tarafindan yapılmıştır. Sosyal Beceri Envanteri 90 madde ve altı alt boyuttan oluşmaktadır ve her alt boyutta 15 madde bulunmaktadır. Bu alt boyutlar Tablo 3'de yer almaktadır:

Tablo 3. Sosyal Beceriyi Oluşturan Boyutlar ve Boyutları Oluşturan Maddeler

\begin{tabular}{|l|l|}
\hline \multicolumn{1}{|c|}{ Boyutlar } & \multicolumn{1}{c|}{ Maddeler } \\
\hline 1-Duyuşsal Anlatımc1lık & 1., 7., 13., 19., 25., 31., 37., 43., 49., 55., 61., 67., 73., 79. ve 85. \\
\hline 2-Duyuşsal Duyarlı1ık & 2., 8., 14., 20., 26., 32., 38., 44., 50., 56., 62., 68., 74., 80. ve 86. \\
\hline 3-Duyuşsal Kontrol & 3., 9., 15., 21., 27., 33., 39., 45., 51., 57., 63., 69., 75., 81. ve 87. \\
\hline 4-Sosyal Anlatımc1l1k & 4., 10., 16., 22., 28., 34., 40., 46., 52., 58., 64., 70., 76., 82. ve 88. \\
\hline 5-Sosyal Duyarl111k & 5., 11., 17., 23., 29., 35., 41., 47., 53., 59., 65., 71., 77., 83. ve 89. \\
\hline 6-Sosyal Kontrol & 6., 12., 18., 24., 30., 36., 42., 48., 54., 60., 66., 72., 78., 84. ve 90. \\
\hline
\end{tabular}

Envanterdeki maddelere beşli likert tipi bir cevaplama anahtarı hazırlanmıştır ve anahtarda en düşük puan 1 , en yüksek puan ise 5'dir. Veri toplama aracındaki maddelerin cevap seçenekleri; "Hiç benim gibi değil" 1, "Biraz benim gibi" 2, "Benim gibi" 3, "Oldukça benim gibi" 4 ve "Tamamen benim gibi" 5 puan olarak hesaplanmaktadır. Envanterdeki bazı maddelerin puanları ise tersine çevrilerek hesaplanmaktadir (1., 3., 5., 9., 10., 15., 17., 18., 21., 24., 25., 30., 36., 37., 39., 41., 43., 48., 49., 54., 56., 60., 64., 66., 67., 69., 72., 73., 76., 81., 84. ve 85. sorular). Bir kişi envanterin bütününden toplam puan olarak en düşük 90, en yüksek ise 450 puan alabilir. Alt ölçeklerden ise en az 15, en çok ise 75 puan alınabilmektedir.

Sosyal beceri envanterinin yurt dışında yapılan geçerlik ve güvenirlik çalışmaları Riggio $(1986,1989)$ tarafından gerçekleştirilmiştir. Testin güvenirliği testin tekrarı ve iç tutarlılık yöntemleriyle ayrı ayrı hesaplanmıştır. İki hafta ara ile yapılan testin tekrarı yöntemi ile 40 adaya uygulama yapılmıştır. Ölçeğin orijinalinden elde edilen güvenirlik katsayısı $r_{x}=.94$ olarak bulunmuştur. Alt ölçeklerden elde edilen güvenirlik katsayıları ise $r_{x}=.81$ ile $r_{x}=.96$ arasında değişmektedir. Sosyal Beceri Envanteri üzerinde yapılan diğer bir güvenirlik hesaplaması da Cronbach Alpha güvenirlik yöntemidir. Bu yöntemle elde edilen alt ölçek puanı güvenirlik katsayıları $\mathrm{r}_{\mathrm{x}}=.62$ ile .87 arasında bulunmuştur. Ortalama iç tutarlılık katsayısı ise erkekler için .84 kızlar için ise .80 olarak hesaplanmıştır (Yüksel, 2004, s. 31-32).

Sosyal Beceri Envanteri, Yüksel (1986) tarafindan 53 üniversite öğrencisine dört hafta ara ile iki kez uygulanmış ve testin tekrarı yöntemi ile hesaplanan toplam puana ilişkin güvenirlik katsayısı tüm ölçek için $r_{x}=.92$ bulunmuştur. Alt ölçeklerden elde edilen güvenirlik katsayıları ise $r_{x}=.80$ ile .89 arasında değişmektedir. Sosyal Beceri Envanteri güvenirliğini hesaplamak için bir başka yöntem olarak da iç tutarlılık hesaplanmıştır. Sosyal Beceri Envanteri 182 öğrenciye uygulanmış iç tutarlılık katsayısı (Cronbach alpha) .85 olarak hesaplanmıştır. Alt ölçeklerden elde edilen iç tutarlık katsayıları $r_{x}=.56$ ile .82 arasında değişmektedir. Duyuşsal anlatımcılık için .56; Duyuşsal duyarlık için .80; Duyuşsal kontrol için .75; Sosyal anlatımcılık için .82; Sosyal duyarlık için .72; Sosyal kontrol için ise .81 şeklinde çıkmıştır (Yüksel, 2004, s. 39-40). Bu araştırma için ölçek üzerinde yapılan analizler sonucunda ise ölçeğin güvenirliği $r_{x}=.838$ bulunmuştur.

Yüksel (2004), Sosyal Beceri Envanteri’nin geçerlik çalışmasını kapsam geçerliği ve benzer ölçekler geçerliği olmak üzere iki yöntem kullanarak yapmıştır. Sosyal Beceri Envanteri geçerlik çalışmalarında başvurulan ilk yöntem kapsam geçerliğidir. Alanda uzman olan kişiler Sosyal Beceri Envanterini incelemişler ve ölçeğin sosyal becerileri ölçebilecek nitelikte olduğunu belirtmişlerdir. Geçerlik çalışmalarında başvurulan ikinci yöntem ise benzer ölçekler geçerliğidir. Sosyal Beceri Envanteri'nin benzer ölçekler geçerliğini belirlemek için Synder tarafından geliştirilip Bacanlı tarafindan 1990 yılında Türkçeye uyarlanan Kendini Ayarlama Ölçeği ölçüt olarak kullanılmıştır. İngilizce ve Tarih bölümü ikinci sınıf öğrencilerine Sosyal Beceri Envanteri ve Kendini Ayarlama Ölçeği birlikte uygulanmıştır. Her iki ölçekten elde edilen puanlar arasında .63 ( $\mathrm{n}=37)$ korelasyon bulunmuştur (Yüksel, 2004, s. 41). 
Bu bulgular 1şığında Sosyal Beceri Envanteri’nin güvenirliği ve geçerliği araştırmada kullanılabilecek düzeyde olduğu kanısına varılmıştır.

\subsection{Veri Toplama Süreci}

Araştırmaya ilişkin veriler 2012-2013 bahar yarıyılında ders saatleri içinde derse giren öğretim elemanlarının yardımı ile araştırmacının kendisi tarafindan toplanmıştır.

Verileri toplamak amacıyla belirlenen araştırma grubundaki sınıflara ölçeklerin uygulanacağı saatler belirlenmiştir. Kararlaştırılan saatlerde "Sosyal A $\breve{g}$ Siteleri Kullanım Anketi" ve "Sosyal Beceri Envanteri” birlikte uygulanmıştır. Öğretmen adaylarının kişisel bilgilerini elde etmek için ayrıca bir bilgi formu kullanılmamış, gerekli bilgiler ölçekler üzerinde belirtilen sorularla toplanmıştır. Uygulamadan önce veri toplama araçları ile ilgili yönergeler okunmuş ve uygulamayla ilgili bilgi verilmiştir. Veri toplama araçlarında herhangi bir karışıklığa neden olmamak için her iki veri toplama aracı birbirine eklenmiş olarak verilmiştir. Veri toplama araçları, uygulamanın yapıldığı gün sınıfta bulunan öğrenciler tarafından cevaplanmış, anketler uygulanırken öğrencilere gerekli süre tanınarak okumadan cevap vermeleri engellenmeye çalışılmıştır. Uygulamada herhangi bir sorunla karşılaşılmamıştır.

\subsection{Verilerin Çözümlenmesi}

Araştırmada elde edilen veriler kişisel bilgiler, sosyal ağ sitelerini kullanım durumlarını ve sosyal anlatımcılık beceri düzeylerini belirten veriler olmak üzere üçe ayrılmaktadır. Araştırmada kullanılan veri toplama araçlarının uygulanması tamamlandıktan sonra cevap kâğıtları kontrol edilmiş ve eksik bilgi verenler değerlendirme dışı bırakılmıştır. Elde edilen veriler bilgisayar ortamına kodlanarak girilmiş ve istatistiksel işlemler yapılması için hazır hale getirilmiştir. Bilgilerin analizi Mann Whitney U Testi ve Kruskal Wallis Varyans Analizi testleri uygulanarak ve SPSS paket programı yardımıyla gerçekleştirilmiştir.

Araştırmanın alt problemlerinin analizi için uygun istatistiksel yöntemleri belirlemek amaciyla normal dağılıma uygunluk analizi yapılmıştır. Lilliefors Significance Correction yapılarak elde edilen Test of Normality sonuçları Tablo 4' de gösterilmiştir.

Tablo 4. Normal Dağılıma Uygunluk Analizi Sonuçları

\begin{tabular}{|c|c|c|c|c|}
\hline & N & X & S.s & P \\
\hline Sosyal Anlatımcilik & 701 & 45,22 & 9,93 &, 000 \\
\hline
\end{tabular}

Yapılan analiz sonucunda öğretmen adaylarının sosyal anlatımcılık becerilerine ilişkin puanlarının Test of Normality sonuçlarına göre, (p) anlamlılık değeri sosyal anlatımcılık alt boyutu için $p=, 000$ 'dır. $\mathrm{Bu}$ değer 0,05 anlamlılık seviyesinden küçüktür. Bu nedenle öğretmen adaylarının sosyal anlatımcılık beceri puanlarının normal dağılıma sahip olmadığı söylenebilir.

Veriler normal dağılım göstermediğinden parametrik testin varsayımlarını yerine getirmemektedir. Dolayısıyla verilerin analizinde Non-parametrik testlerden Mann Whitney U ve Kruskal-Wallis varyans analizi kullanılmıştır. Verilerin analizinde anlamlılık değeri $\mathrm{p}<, 05$ olarak alınmıştır.

Kruskal Wallis varyans analizi sonucunda anlamlı bir fark bulunduğu takdirde farkın hangi gruplar arasında olduğunu belirlemek için Bonferroni düzeltmeli Mann Whitney U testi ile ikili karşılaştırmalar yapılmıştır. Mann Whitney U testi ile ikili karşılaştırmalar yapılırken, ölçme işlemine karışabilecek I. tip hatanın önlenebilmesi için Bonferroni düzeltmesi uygulanmıştır. Aksi takdirde karşılaştırılan gruplar arasında gerçekte anlamlı bir fark bulunmadığı halde anlamlı bir farkın olduğu yanılgısına düşülebilir. Bonferroni düzeltmesine göre, Mann Whitney $U$ testi sonucunda elde edilen anlamll1ık değeri (p), 0.05 düzeyinde test edilmemektedir. Karşılaştırmalarda 0.05 değerinin yerine, 0.05 'in karşılaştırılacak ikili grupların sayısına bölünmesiyle elde edilen değer anlamlı farklılığın göstergesi olarak kabul edilmektedir (Field, 2009, s. 565).

Verilerin analiz edilmesinden sonra ortaya çıkan sonuçlar, araştırmanın alt problemlerine cevap olabilecek bir düzen içinde bulgular bölümünde sunulmuştur. 


\section{BULGULAR}

Bu bölümde araştırmaya katılan öğretmen adaylarının sosyal ağ sitelerini kullanma durumlarına göre sosyal anlatımcılık beceri düzeyleri incelenmiş ve analizler sonucu elde edilen bulgular tablolaştırılarak sunulmuştur.

\subsection{Sosyal Anlatımcılık Boyutuna İlişkin Puanların "Sosyal Ă̆ Sitelerine Üye Olma Durumuna" Göre İncelenmesi}

$\mathrm{Bu}$ alt amaca ilişkin veriler Mann Whitney $\mathrm{U}$ testi ile analiz edilmiştir. Elde edilen bulgular Tablo 5'de sunulmuştur.

Tablo 5. Sosyal Anlatımcılık Boyutuna İlişkin Puanların "Sosyal Ağ Sitelerine Üye Olma Durumuna" Göre İncelenmesine İlişkin Mann Whitney U Testi Sonuçları

\begin{tabular}{|c|c|c|c|c|c|c|}
\hline & $\mathbf{N}$ & Sira Ortalaması & Sira Toplamı & $\mathbf{U}$ & $\mathbf{Z}$ & $\mathbf{P}$ \\
\hline Evet & 619 & 364.82 & 225821.00 & \multirow{2}{*}{16827.00} & -4.965 & \multirow{2}{*}{.000} \\
\cline { 1 - 5 } Hayır & 82 & 246.71 & 20230.00 & & \\
\hline
\end{tabular}

Tablo 5 incelendiğinde sosyal ağ sitelerine üye olan öğretmen adaylarının sosyal anlatımcılık alt boyutuna ilişkin puanlarının sıra değerlerinin ortalamasının 364.82, sosyal ağ sitelerine üye olmayan ögretmen adaylarının sosyal anlatımcılık alt boyutuna ilişkin puanlarının sıra değerlerinin ortalamasının 246.71 olduğu görülmektedir. Mann Whitney $U$ testi sonuçlarına göre; $p=0.000<0.05$ olduğundan öğretmen adaylarının sosyal anlatımcılık puanları, sosyal ağlara üye olma durumlarına göre anlamlı bir farklılık göstermektedir. Sosyal ağ sitelerine üye olan öğretmen adaylarının sosyal anlatımcılık alt boyutuna ilişkin puanlarının sıra ortalaması, sosyal ağ sitelerine üye olmayan öğretmen adaylarının puanlarının sıra ortalamasından anlamlı olarak daha yüksektir. Bu bulgulara göre sosyal ağlara üyelik durumunun öğretmen adaylarının sosyal anlatımcılık becerileri üzerinde etkili bir değişken olduğu söylenebilir.

\subsection{Sosyal Anlatımcılık Boyutuna İlişkin Puanların "Sosyal A ğ Sitelerine Üye Olunan Süreye" Göre İncelenmesi}

$\mathrm{Bu}$ alt amaca ilişkin veriler için Kruskal-Wallis varyans analizi kullanılmıştır. Kruskal Wallis varyans analizi sonucuna göre gruplar arasındaki farkın anlamlı olduğu görülmektedir (Tablo 6). Anlamlı farkın hangi gruplar arasında olduğunu belirlemek için Bonferroni düzeltmeli Mann Whitney U testi uygulanmıştır. Gruplar arasında gözlenen bu anlamlı farkın hangi gruplar arasında olduğunun belirlenmesi için Mann Whitney $U$ testi ile yapılan ikili karşılaştırmalarda karşılaştırılacak grupların sayıs1 $6(1-2,1-3,1-4,2-3,2-4,3-4)$ olduğundan, 0.05 değeri 6'ya bölünmüştür. Buna göre öğretmen adaylarının sosyal ă̆ sitelerine üye oldukları süreye göre ikili karşılaştırmalar yapılırken anlamlılık, 0.083 düzeyinde test edilmiştir. Elde edilen bulgular Tablo 6' da sunulmuştur.

Tablo 6. Sosyal Anlatımcılık Boyutuna İlişkin Puanların "Sosyal Ağ Sitelerine Üye Olunan Süreye" Göre İncelenmesine İlişkin Kruskal-Wallis Varyans Analizi ve Mann Whitney U Testi Sonuçları

\begin{tabular}{|c|c|c|c|c|c|c|}
\hline & $\mathbf{N}$ & Sira Ortalaması & Sd & $\mathbf{X}^{2}$ & $\mathbf{P}$ & Anlamlı Farkın Olduğu Gruplar \\
\hline $1-2 \mathrm{y} 1 \mathrm{l}$ & 79 & 274.03 & \multirow{4}{*}{3} & \multirow{4}{*}{15.603} & \multirow{4}{*}{.001} & \multirow{4}{*}{$\begin{array}{l}1-2 \text { y1l ile } 4 \text { yıldan fazla - (.004) } \\
3-4 \text { y1l ile } 4 \text { yıldan fazla - (.006) }\end{array}$} \\
\hline $2-3 \mathrm{y} 1 \mathrm{l}$ & 90 & 278.77 & & & & \\
\hline $3-4$ y1l & 129 & 286.33 & & & & \\
\hline 4 yıldan fazla & 321 & 337.12 & & & & \\
\hline
\end{tabular}

Tablo 6 incelendiğinde sosyal ağ sitelerine üye oldukları süreye göre öğretmen adaylarının sosyal anlatımcılık alt boyutuna ilişkin puanlarının sıra değerlerinin ortalaması şöyledir: Sosyal ağ sitelerine üyelik süresi "1-2 yıl" olanların sıra değerlerinin ortalaması 274.03, "2-3 yıl" olanların sira değerlerinin ortalaması 278,77, "3-4 yıl" olanların sıra değerlerinin ortalaması 286.33 ve "4 yıldan fazla" olanların sira değerlerinin ortalaması ise 337.12 'dir. 
Kruskal-Wallis varyans analizi sonuçlarına göre, $p=0.001<0.05$ olduğundan öğretmen adaylarının sosyal anlatımcılık puanları, sosyal ağ sitelerine üye oldukları süreye göre anlamlı bir farklılık göstermektedir. $\mathrm{Bu}$ farkın hangi gruplar arasında olduğunu belirlemek için yapılan Bonferroni düzeltmeli Mann Whitney U testi sonuçlarına göre ise; sosyal ağ sitelerine üye oldukları süre "4 yıldan fazla" olan öğretmen adaylarının sosyal anlatımcılık boyutuna ilişkin puanlarının sıra ortalaması, sosyal ağ sitelerine üye oldukları süre "1-2 yıl" ve "3-4 yıl" olan öğretmen adaylarının puanlarının sıra ortalamasından anlamlı olarak daha yüksektir. Bu bulgulara göre sosyal ağ sitelerine üye olma süresinin öğretmen adaylarının sosyal anlatımc1lık becerileri üzerinde etkili bir değişken olduğu söylenebilir.

\subsection{Sosyal Anlatımcılık Boyutuna İlişkin Puanların “Aktif Olarak Kullanılan Sosyal A $\breve{g}$ Sayısına" Göre İncelenmesi}

Bu alt amaca ilişkin veriler için Kruskal-Wallis varyans analizi kullanılmıştır. Kruskal Wallis varyans analizi sonucuna göre gruplar arasındaki farkın anlamlı olduğu görülmektedir (Tablo 7). Anlamlı farkın hangi gruplar arasında olduğunu belirlemek için Bonferroni düzeltmeli Mann Whitney $U$ testi uygulanmıştır. Gruplar arasında gözlenen bu anlamlı farkın hangi gruplar arasında olduğunun belirlenmesi için Mann Whitney $U$ testi ile yapılan ikili karşılaştırmalarda karşılaştırılacak grupların sayısı $3(1-2,1-3,2-3)$ olduğundan, 0.05 değeri 3'e bölünmüştür. Buna göre öğretmen adaylarının aktif olarak kullandıkları sosyal ağ sayısına göre ikili karşılaştırmalar yapılırken anlamlılık, 0.016 düzeyinde test edilmiştir. Elde edilen bulgular Tablo 7'de sunulmuştur.

Tablo 7. Sosyal Anlatımcıılık Boyutuna İlişkin Puanların "Aktif Olarak Kullanılan Sosyal Ağ Sayısına" Göre İncelenmesine İlişkin Kruskal-Wallis Varyans Analizi ve Mann Whitney U Testi Sonuçları

\begin{tabular}{|c|c|c|c|c|c|c|}
\hline & $\mathbf{N}$ & Sira Ortalaması & Sd & $\mathbf{X}^{2}$ & $\mathbf{P}$ & Anlamlı Farkın Olduğu Gruplar \\
\hline 2'den az & 334 & 289.85 & \multirow{3}{*}{2} & \multirow{3}{*}{15.145} & \multirow{3}{*}{.001} & \multirow{3}{*}{$\begin{array}{l}\text { 2'den az ile 2-4 aras1 - (.014) } \\
\text { 2'den az ile 4'den fazla - (.001) } \\
\text { 2-4 arasi ile 4'den fazla - (.012) }\end{array}$} \\
\hline $2-4$ aras1 & 261 & 325.79 & & & & \\
\hline 4'den fazla & 24 & 418.63 & & & & \\
\hline
\end{tabular}

Tablo 7 incelendiğinde aktif olarak kullandıkları sosyal ağ sayısına göre öğretmen adaylarının sosyal anlatımcılık alt boyutuna ilişkin puanlarının sıra değerlerinin ortalaması şöyledir: "2'den az" olanların sira değerlerinin ortalaması 289.85 , "2-4 arası" olanların sira değerlerinin ortalaması 325.79 ve " 4 'den fazla" olanların sira değerlerinin ortalaması ise 418.63 'dür.

Kruskal-Wallis varyans analizi sonuçlarına göre, $p=0.001<0.05$ olduğundan öğretmen adaylarının sosyal anlatımcılık puanları, aktif olarak kullandıkları sosyal ăg sayısına göre anlamlı farklılık göstermektedir. $\mathrm{Bu}$ farkın hangi gruplar arasında olduğunu belirlemek için yapılan Bonferroni düzeltmeli Mann Whitney U testi sonuçlarına göre ise; aktif olarak kullandıkları sosyal ağ sayısı " 4 den fazla" olan öğretmen adaylarının sosyal anlatımcılık boyutuna ilişkin puanlarının sıra ortalaması, aktif olarak kullandıkları sosyal ağ sayıs1 " 2' den az" ve "2-4 arası" olan öğretmen adaylarının puanlarının sıra ortalamasından anlamlı olarak daha yüksektir. Ayrıca aktif olarak kullandıkları sosyal ağ sayısı "2-4 arası" olan ögretmen adaylarının sosyal anlatımcılık puanlarının sıra ortalaması, "2 den az" olan öğretmen adaylarının puanlarının sıra ortalamasından anlamlı olarak daha yüksektir. Bu bulgulara göre aktif olarak kullanılan sosyal ağ sayısının öğretmen adaylarının sosyal anlatımcılık puanları üzerinde etkili bir değişken olduğu ve aktif olarak kullanılan sosyal ağ sayısı arttıkça sosyal anlatımcılık becerilerinin arttı̆̆1 söylenebilir.

\subsection{Sosyal Anlatımcılık Boyutuna İlişkin Puanların "Sosyal Ă̆ Sitelerinde Bir Günde Ortalama Geçirilen Süreye" Göre İncelenmesi}

$\mathrm{Bu}$ alt amaca ilişkin veriler için Kruskal-Wallis varyans analizi kullanılmıştır. Kruskal Wallis varyans analizi sonucuna göre gruplar arasındaki farkın anlamlı olduğu görülmektedir (Tablo 8). Anlamlı farkın hangi gruplar arasında olduğunu belirlemek için Bonferroni düzeltmeli Mann Whitney U testi uygulanmıştır. Gruplar arasında gözlenen bu anlamlı farkın hangi gruplar arasında olduğunun belirlenmesi için Mann Whitney U testi ile yapılan ikili karşılaştırmalarda karşılaştırılacak grupların sayısı 3 (1-2, 1-3, 2-3) olduğundan, 0.05 değeri 3'e bölünmüştür. Buna göre öğretmen adaylarının sosyal 
ağ sitelerinde bir günde ortalama geçirdikleri süreye göre ikili karşılaştırmalar yapılırken anlamll1ık, 0.016 düzeyinde test edilmiştir. Elde edilen bulgular Tablo 8'de sunulmuştur.

Tablo 8. Sosyal Anlatımcılık Boyutuna İlişkin Puanların "Sosyal Ağ Sitelerinde Bir Günde Ortalama Geçirilen Süreye" Göre İncelenmesine İlişkin Kruskal-Wallis Varyans Analizi ve Mann Whitney U Testi Sonuçları

\begin{tabular}{|c|c|c|c|c|c|c|}
\hline & $\mathbf{N}$ & Sira Ortalaması & Sd & $\mathbf{X}^{2}$ & $\mathbf{P}$ & Anlamlı Farkın Olduğu Gruplar \\
\hline 1 saatten az & 300 & 286.99 & \multirow{3}{*}{2} & \multirow{3}{*}{11.267} & \multirow{3}{*}{.004} & \multirow{3}{*}{$\begin{array}{c}1 \text { saatten az ile } 1-2 \text { saat }-(.015) \\
1 \text { saatten az ile } 3 \text { saatten fazla-(.004) }\end{array}$} \\
\hline $1-2$ saat & 237 & 324.16 & & & & \\
\hline 3 saatten fazla & 82 & 353.26 & & & & \\
\hline
\end{tabular}

Tablo 8 incelendiğinde sosyal ağ sitelerinde bir günde ortalama geçirdikleri süreye göre öğretmen adaylarının sosyal anlatımcılık boyutuna ilişkin puanlarının sıra değerlerinin ortalaması şöyledir: "1 saatten az" zaman geçirenlerin sıra değerlerinin ortalaması 286.99 , "1-2 saat" zaman geçirenlerin sıra değerlerinin ortalaması 324.16 ve "3 saatten fazla" zaman geçirenlerin sıra değerlerinin ortalaması ise 353.26'dır.

Kruskal-Wallis varyans analizi sonuçlarına göre, $p=0.004<0.05$ olduğundan öğretmen adaylarının sosyal anlatımcılık puanları bir günde ortalama olarak sosyal ağlarda geçirdikleri süreye göre anlamlı bir farklılık göstermektedir. Bu farkın hangi gruplar arasında olduğunu belirlemek için yapılan Bonferroni düzeltmeli Mann Whitney U testi sonuçlarına göre ise sosyal ağ sitelerinde bir günde ortalama "1-2 saat" zaman geçiren öğretmen adaylarının sosyal anlatımcılık boyutuna ilişkin puanlarının sıra ortalaması, "1 saatten az" zaman geçiren öğretmen adaylarının puanlarının sıra ortalamasından anlamlı olarak daha yüksektir. Aynı zamanda sosyal ağ sitelerinde bir günde ortalama "3 saatten fazla" zaman geçiren ögretmen adaylarının sosyal anlatımcılık boyutuna ilişkin puanlarının sıra ortalaması da "1 saatten az" zaman geçiren öğretmen adaylarının puanlarının sıra ortalamasından anlamlı olarak daha yüksektir. $\mathrm{Bu}$ bulgulara göre sosyal ağ sitelerinde bir günde ortalama geçirilen sürenin öğretmen adaylarının sosyal anlatımcılık becerileri üzerinde etkili bir değişken olduğu söylenebilir.

\subsection{Sosyal Anlatımcılık Boyutuna İlişkin Puanların "Sosyal A ğların En Fazla Kullanııa Amacına" Göre İncelenmesi}

$\mathrm{Bu}$ alt amaca ilişkin veriler için Kruskal-Wallis varyans analizi kullanılmıştır. Elde edilen bulgular Tablo 9'da sunulmuştur.

Tablo 9. Sosyal Anlatımcılık Boyutuna İlişkin Puanların "Sosyal Ağların En Fazla Kullanılma Amacına” Göre İncelenmesine İlişkin Kruskal-Wallis Varyans Analizi Testi Sonuçları

\begin{tabular}{|c|c|c|c|c|c|c|}
\hline & $\mathbf{N}$ & \begin{tabular}{c|} 
Sura \\
Ortalaması
\end{tabular} & Sd & $\mathbf{X}^{2}$ & $\mathbf{P}$ & $\begin{array}{l}\text { Anlamlı Farkın } \\
\text { Olduğu Gruplar }\end{array}$ \\
\hline Sohbet etmek & 89 & 312.88 & \multirow{6}{*}{5} & \multirow{6}{*}{5.610} & \multirow{6}{*}{.346} & \multirow{6}{*}{ - } \\
\hline Paylaşımda bulunmak & 83 & 343.42 & & & & \\
\hline Ödev ve proje için araştırma yapmak & 61 & 298.32 & & & & \\
\hline Arkadaşlarımın paylaşımlarını takip etmek & 129 & 286.91 & & & & \\
\hline Grup/topluluk güncellemelerini takip etmek & 190 & 315.66 & & & & \\
\hline Diğer & 67 & 303.81 & & & & \\
\hline
\end{tabular}

Tablo 9 incelendiğinde sosyal ağları en fazla kullanma amaçlarına göre öğretmen adaylarının sosyal anlatımcılık boyutuna ilişkin puanlarının sıra değerlerinin ortalaması şöyledir: "sohbet etmek" için kullananların sıra değerlerinin ortalaması 312.88 , "paylaşımda bulunmak" için kullananların sıra değerlerinin ortalamas1 343.42, "ödev ve proje için araştırma yapmak" için kullananların sıra değerlerinin ortalaması 298.32, "arkadaşlarının paylaşımlarını takip etmek" için kullananların sıra değerlerinin ortalaması 286.91 "grup/topluluk güncellemelerini takip etmek" için kullananların sıra değerlerinin ortalaması 315.66 ve "diğer" amaçlar için kullananların sıra değerlerinin ortalaması ise 303.81'dir. 
Kruskal-Wallis varyans analizi sonuçlarına göre, $p=0.346>0.05$ olduğundan öğretmen adaylarının sosyal anlatımcılık puanları, sosyal ağları en fazla kullanma amaçlarına göre anlamlı bir farklılık göstermemektedir. Bu bulgulara göre sosyal ağların en fazla kullanılma amacının öğretmen adaylarının sosyal anlatımcılık becerileri üzerinde etkili bir değişken olmadığı söylenebilir.

\subsection{Sosyal Anlatımcılık Boyutuna İlişkin Puanların "Sosyal Ă̆ Sitelerinde Yer Alan İçeriklere Yorum Yazma Durumuna” Göre İncelenmesi}

Bu alt amaca ilişkin veriler Mann Whitney U testi ile analiz edilmiştir. Elde edilen bulgular Tablo 10' da sunulmuştur.

Tablo 10. Sosyal Anlatımcılık Boyutuna İlişkin Puanların "Sosyal Ağ Sitelerinde Yer Alan İçeriklere Yorum Yazma Durumuna” Göre İncelenmesine İlişkin Mann Whitney U Testi Sonuçları

\begin{tabular}{|l|c|c|c|c|c|c|}
\hline & $\mathbf{N}$ & Sıra Ortalaması & Sıra Toplamı & $\mathbf{U}$ & $\mathbf{Z}$ & $\mathbf{P}$ \\
\hline Evet & 428 & 329.58 & 141058.50 & \multirow{2}{*}{32495.50} & -4.079 & \multirow{2}{*}{.000} \\
\hline Hayır & 191 & 266.13 & 50831.50 & & \\
\hline
\end{tabular}

Tablo 10 incelendiğinde sosyal ağ sitelerinde yer alan içeriklere yorum yazan öğretmen adaylarının sosyal anlatımcılık alt boyutuna ilişkin puanlarının sıra değerlerinin ortalamasının 329.58, yorum yazmayan öğretmen adaylarının sosyal anlatımcılık alt boyutuna ilişkin puanlarının sıra değerlerinin ortalamasının 266.13 olduğu görülmektedir. Mann Whitney U testi sonuçlarına göre; $p=0.000<0.05$ olduğundan öğretmen adaylarının sosyal anlatımcılık puanları, sosyal ağ sitelerinde yer alan içeriklere yorum yazma durumlarına göre anlamlı bir farklılık göstermektedir.

Sosyal ağ sitelerinde yer alan içeriklere yorum yazan öğretmen adaylarının sosyal anlatımcılık boyutuna ilişkin puanlarının sıra ortalaması, yorum yazmayan öğretmen adaylarının puanlarının sıra ortalamasından anlamlı olarak daha yüksektir. Bu bulgulara göre sosyal ağ sitelerinde yer alan içeriklere yorum yazma durumunun öğretmen adaylarının sosyal anlatımcılık becerileri üzerinde etkili bir değişken olduğu söylenebilir.

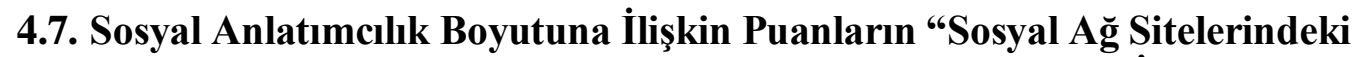 Yazışmalarda Yüz Simgelerini Kullanma Durumuna” Göre İncelenmesi}

Bu alt amaca ilişkin veriler Mann Whitney U testi ile analiz edilmiştir. Elde edilen bulgular Tablo 11' de sunulmuştur.

Tablo 11. Sosyal Anlatımcılık Boyutuna İlişkin Puanların "Sosyal Ağ Sitelerindeki Yazışmalarda Yüz Simgelerini Kullanma Durumuna” Göre İncelenmesine İlişkin Mann Whitney U Testi Sonuçları

\begin{tabular}{|l|c|c|c|c|c|c|}
\hline & $\mathbf{N}$ & Sira Ortalaması & Sira Toplamı & $\mathbf{U}$ & $\mathbf{Z}$ & $\mathbf{P}$ \\
\cline { 1 - 4 } Evet & 531 & 319.00 & 169388.00 & \multirow{2}{*}{18586.00} & -3.077 & \multirow{2}{*}{.002} \\
\hline Hayır & 88 & 255.70 & 22502.00 & & & \\
\hline
\end{tabular}

Tablo 11 incelendiğinde sosyal ağ sitelerindeki yazışmalarında yüz simgelerini kullanan öğretmen adaylarının sosyal anlatımcılık alt boyutuna ilişkin puanlarının sıra değerlerinin ortalamasının 319.00, yüz simgelerini kullanmayan öğretmen adaylarının sosyal anlatımcılık alt boyutuna ilişkin puanlarının sıra değerlerinin ortalamasının 255.70 olduğu görülmektedir. Mann Whitney U testi sonuçlarına göre; $\mathrm{p}=0.002<0.05$ olduğundan öğretmen adaylarının sosyal anlatımcılık puanları, sosyal ağ sitelerindeki yazışmalarında yüz simgelerini kullanma durumlarına göre anlamlı bir farklılık göstermektedir. Sosyal a ̆ sitelerindeki yazışmalarında yüz simgeleri kullanan öğretmen adaylarının sosyal anlatımcılık boyutuna ilişkin puanlarının sıra ortalaması, yüz simgelerini kullanmayan öğretmen adaylarının puanlarının sıra ortalamasından anlamlı olarak daha yüksektir. Bu bulgulara göre sosyal ağ sitelerindeki yazışmalarda yüz simgeleri kullanma durumunun öğretmen adaylarının sosyal anlatımcılık becerileri üzerinde etkili bir değişken olduğu söylenebilir. 


\section{Sonuç}

Öğretmen adaylarının sosyal anlatımcılık becerileri; sosyal ağlara üye olma durumlarına, sosyal ağ sitelerine üye olma sürelerine, aktif olarak kullandıkları sosyal ağ sayısına, sosyal ağ sitelerinde bir günde ortalama geçirdikleri süreye, sosyal ağ sitelerinde yer alan içeriklere yorum yazma durumlarına, sosyal ağ sitelerindeki yazışmalarında yüz simgelerini kullanma durumlarına göre anlamlı bir farklılık göstermiştir. Ancak sosyal ağları en fazla kullanma amaçlarına göre anlamlı bir farklılık saptanmamıştır. Sosyal anlatımcılıkla ilgili önemli bazı sonuçlar aşağıda yer almaktadır:

- Sosyal ağ sitelerine üye olan öğretmen adaylarının sosyal anlatımcılık beceri düzeyleri, sosyal ağ sitelerine üye olmayan öğretmen adaylarının sosyal anlatımcılık beceri düzeylerinden anlamlı olarak daha yüksektir.

- Sosyal ağ sitelerine üye oldukları süre "4 yıldan fazla" olan öğretmen adaylarının sosyal anlatımc1lık beceri düzeyleri, sosyal ağ sitelerine üye oldukları süre "1-2 yıl" ve "3-4 yıl" olan öğretmen adaylarının sosyal anlatımcılık beceri düzey düzeylerinden anlamlı olarak daha yüksektir.

- Aktif olarak kullandıkları sosyal ağ sayısı "4 den fazla" olan öğretmen adaylarının sosyal anlatımcılık beceri düzeyleri, aktif olarak kullandıkları sosyal ağ sayısı "2' den az" ve "2-4 arası" olan öğretmen adaylarının sosyal anlatımcılık beceri düzeylerinden anlamlı olarak daha yüksektir. Ayrıca aktif olarak kullandıkları sosyal ağ sayısı "2-4 arası" olan öğretmen adaylarının sosyal anlatımcılık beceri düzeyleri, " 2 den az" olan öğretmen adaylarının sosyal anlatımcılık beceri düzeylerinden anlamlı olarak daha yüksektir.

- Sosyal ağ sitelerinde bir günde ortalama "1-2 saat" ve "3 saatten fazla" zaman geçiren öğretmen adaylarının sosyal anlatımcılık beceri düzeyleri, "1 saatten az" zaman geçiren öğretmen adaylarının sosyal anlatımcılık beceri düzeylerinden anlamlı olarak daha yüksektir.

- Sosyal ăg sitelerinde yer alan içeriklere yorum yazan öğretmen adaylarının sosyal anlatımcılık beceri düzeyleri, yorum yazmayan öğretmen adaylarının sosyal anlatımcıllık beceri düzeylerinden anlamlı olarak daha yüksektir.

- Sosyal ağ sitelerindeki yazışmalarında yüz simgeleri kullanan öğretmen adaylarının sosyal anlatımcılık beceri düzeyleri, yüz simgelerini kullanmayan öğretmen adaylarının sosyal anlatımcılık beceri düzeylerinden anlamlı olarak daha yüksektir.

\section{Tartışma}

Araştırmada öğretmen adaylarının sosyal ağ sitelerini kullanma durumlarına göre sosyal anlatımcılık beceri düzeyleri incelenmiştir. Araştırmanın amacı sosyal ağ sitelerini kullanma durumlarına göre sosyal anlatımcılık beceri düzeylerindeki değişimi belirlemektir.

Araştırmada öğretmen adaylarının sosyal ağ sitelerine üye olma durumlarına, sosyal ağ sitelerine üye oldukları süreye, aktif olarak kullandıkları sosyal ağ sayısına, sosyal ağ sitelerinde bir günde ortalama geçirdikleri süreye, sosyal ağları en fazla kullanma amaçlarına, sosyal ă̆ sitelerinde yer alan içeriklere yorum yazma durumlarına, sosyal ağ sitelerindeki yazışmalarında yüz simgelerini kullanma durumlarına göre sosyal becerilerinde değişiklik olup olmadığı belirlenmeye çalışılmıştır. Sosyal beceri üzerine yapılan çalışmalarda yüz yüze ortamlarda bile sosyal becerinin nasıll ve ne tür davranışlardan oluştuğu, özelliklerinin veya şartlarının neler olduğu konusunda bir uzlaşma sağlanamamıştır (Bacanlı, 2008, s. 37). $\mathrm{Bu}$ nedenle sanal ortamlarda bu davranışların nasıl ifade edildiğini ve nelerden etkilendiğini belirleme konusunda temel bilgilerin oluşmasına ihtiyaç duyulmaktadır.

Sosyal ağ sitelerine üye olan öğretmen adaylarının sosyal anlatımcılık becerilerinin bu durumdan olumlu yönde etkilendiği ortaya çıkmıştır. Sosyal ağ sitelerine üyeliği olan öğretmen adaylarının sosyal anlatımcillk becerilerinin bu durumdan olumlu etkilenmesi, bireylerin sahip olduklar1 sosyal becerileri farklı ortamlarda uygulayarak genelleştirebilme ve kalıcı hale getirebilme imkânına sahip olmaları ile açıklanabilir. Çünkü sosyal becerilerin genelleştirilebilmesi ve kalıcı hale getirilebilmesi için farklı 
ortamlarda kullanılabilmesi gerekir (Akkök, 2003, s. 121). Ayrıca sosyal ağlar mesajlaşma, arkadaşlarla iletişim kurma, etkileşimde bulunma ve gruplara katılma ve işbirliği gibi etkinlikler için kullanılabildiğinden (Gülbahar, Kalelioğlu ve Madran, 2010), bireylerin ilişki ağını genişletici ve etkinleştirici bir işlev üstlenerek sosyal becerilerini arttırabilir. Hiyerarşinin olmadığı, sınırsız bir hareket alanı sağlayan özgürlükçü bir ortam olarak ifade edebileceğimiz sosyal ağların (Kobak ve Biçer, 2008, s. 571), tüm dünyaya yayılan bir ağ olması, yeni bir sosyal etkileşim ortamı sağlaması, yeni toplumsal ilişki biçimlerinin gelişmesine aracılık etmesi ve çok sayıda seçenekler sunması kullanıcıların büyük bir çoğunluğunun kendilerini daha özgür hissetmelerini sağlamaktadır (Akınoğlu, 2002, s. 165-186).

Sosyal ağ sitelerine üye olunan süreye göre öğretmen adaylarının sosyal anlatımcılık boyutuna ait becerilerinin bu durumdan olumlu yönde etkilendiği ortaya çıkmıştır. Bu durum bireylerin sosyal ağları kullandıkları süre içinde bu ortamın sağladığı avantajlardan dolayı sözel anlatımcılık olarak ifade edilen sosyal anlatımc1lık becerilerinin gelişmesi ile açıklanabilir. Çünkü yüz yüze sosyal ortamlarda söylemekten çekinilen bir takım bilgiler sanal ortamlarda rahatlıkla paylaşılabilmektedir. Ayrıca sosyal ağlar insanların sosyal baskı hissetmemelerini ve tanınmamanın verdiği rahatlıkla kendi iç dünyalarından çıkarak duygu ve düşüncelerini özgürce ifade edebilmelerini sağlamaktadır (Akınoğlu, 2002, s. 240).

Aktif olarak kullanılan sosyal ăg sayısına göre öğretmen adaylarının sosyal anlatımcılık becerilerinin bu durumdan olumlu yönde etkilendiği görülmüştür. Sosyal ağ siteleri iletişime ve etkileşime olanak sağlayan ortamlar olduğundan bireylerin aktif olarak kullandıkları sosyal ağ sayısının fazla olması, diğer insanlarla iletişime ve etkileşime girme konusunda istekli olduklarının bir göstergesi olarak ifade edilebilir. Bu nedenle bireylerin iletişime ve etkileşime girmeye istekli olmalarının, sözel konuşmadaki beceri ve başkalarıyla sosyal yakınlaşmaya girme becerisi olarak ifade edilen sosyal anlatımcılık (Yüksel, 2004, s. 11) boyutunu geliştirdiği düşünülebilir.

Sosyal ağ sitelerinde bir günde ortalama geçirilen süreye göre öğretmen adaylarının sosyal anlatımcılık boyutlarına ait becerilerinin bu durumdan olumlu yönde etkilendiği görülmüştür. Öğretmen adaylarının anlatımcılık becerilerinin bu durumdan olumlu olarak etkilenmesi, sosyal ağ sitelerinde bir günde ortalama geçirilen süre arttıkça bu ortamlarda diğer insanlarla olan etkileşim sıklı̆ğını artması, duygu ve düşüncelerini özgür bir ortamda ifade edebilme imkânına sahip olmaları ile açıklanabilir.

Aktı (2011) tarafından yapılan çalışmada ise evinde bilgisayar sahibi olan öğrencilerin, evinde bilgisayar sahibi olmayan öğrencilere göre sosyal beceri düzeylerinin daha yüksek olduğu saptanmıştır ancak bu fark istatistiksel olarak anlamlı bulunmamıştır. Yine aynı çalışmada gün içinde " 3 saatten fazla" internet kullanan öğrencilerin sosyal beceri düzeylerinin, "hiç kullanmayan", "1 saatten az", "1-2 saat", "2-3 saat" internet kullanan öğrencilere göre sosyal beceri düzeylerinin daha yüksek olduğu ortaya çıkmıştır. Ancak sosyal becerilerde, gün içinde internet kullanma süresi değişkenine göre yapılan analiz sonucunda istatistiksel olarak anlamlı bir farklılığın olmadığı görülmüştür.

Sosyal ă̆ sitelerinde yer alan içeriklere yorum yazan öğretmen adaylarının sosyal anlatımcılık becerilerinin bu durumdan olumlu yönde etkilendiği ortaya çıkmıştır. Sosyal ağ sitelerinde yapılan yorumlar aracılığıyla duygular ve düşünceler başkalarına iletilmeye çalışılır. Bu nedenle yorum yazma ilk olarak doğrudan sözel anlatımcılık olarak da ifade edilen sosyal anlatımcılık boyutunda değerlendirilir. Dolayısıyla yapılan çalışmada sosyal ağ sitelerinde yer alan içeriklere yorum yazan ögretmen adaylarının sosyal anlatımcılık becerilerinin, yorum yazmayanlara göre daha gelişmiş olması beklenir. Ayrıca yorum yazan insanların iletişim kurma konusunda yorum yazmayanlara göre daha istekli oldukları, iletişim kurarak ve sohbetlere dâhil olarak sosyal anlatımcılık becerilerini kullandıkları söylenebilir. Bu durum bireylerin sosyal iletişim kurması ve iletişime katılması olarak tanımlanan sosyal anlatımcıllk becerilerinin daha iyi olabileceğinin bir göstergesi olarak yorumlanabilir.

Sosyal ağ sitelerindeki yazışmalarında yüz simgeleri kullanan öğretmen adaylarının sosyal anlatımcılık boyutlarına ait becerilerinin bu durumdan olumlu yönde etkilendiği ancak diğer boyutlara ait becerilerinde anlamlı bir değişmenin olmadığı ortaya çıkmıştır. Sosyal ağ sitelerinde kullandı̆̆ımız yüz simgeleri, bir bakıma vücut dilimizle (mimikler) gösterdiğimiz bazı duyguları veya hareketleri elektronik ortamda göstermemize imkân tanır (Çakır ve Topçu, 2005, s. 77) ve cümlelere duyuşsal anlam 
katmamızı sağlar. Bu bulgular ışığında günlük yaşantımızda kullandığımız yüz ifadelerinin yerine, sanal ortamlarda yüz simgelerinin kullanıldığı söylenebilir.

Sanal ortamlarda kullanılan yüz simgeleri aracıllğı ile bu ortamlar, duyusal anlatımcılık gibi sözel olmayan becerileri ifade etmek için uygun hale gelebilir ve bu ortamlarda duyuşsal ifadelerin iletimi konusundaki sınırlılıklar azaltılabilir. Sosyal ağ sitelerinde kullanılan yüz simgelerinin bir diğer işlevi ise cümlelerin anlamını kuvvetlendirmek ve ifadeyi zenginleştirmektir. Bu simgeler, bir önceki tümcenin ifadesini pekiştirmek için kullanılabileceği gibi, bir sonraki tümcenin anlamını tamamlamak amacıyla da kullanılabilir (Sarsar, 2012, s. 75-76). Dolayısıyla sosyal ağ sitelerinde kullanılan yüz simgeleri cümlelerle birlikte kullanıldığında cümlenin anlamını kuvvetlendireceği için sosyal anlatımcılık becerilerini de desteklemiş olur.

\section{Öneriler}

$\mathrm{Bu}$ araştırmada öğretmen adaylarının sosyal ağ sitelerini kullanma durumlarına göre sosyal anlatımcılık beceri düzeyleri incelenmiştir. Elde edilen bulgular doğrultusunda aşağıdaki öneriler geliştirilmiştir;

- Daha geniş bir evren ve örneklemle benzer çalışmalar yapılabilir. Bu doğrultuda bu araştırmadan elde edilen sonuçların genellenebilirliğinin artacağı düşünülmektedir.

- Bu çalışmada sosyal ağ sitelerini kullanma durumları genel olarak ele alınmıştır, yapılacak çalışmalarda aktif olarak kullanılan sosyal ağ siteleri ayrı ayrı ele alınarak incelenebilir.

- Araştırmanın sonuçlarına göre öğretmen adaylarının \%88,3'ünün sosyal ă̆ sitelerine üyeliği varken \%11,7'sinin sosyal ağ sitelerine üyeliği bulunmamaktadır. Sosyal ağ sitelerine üye olan öğretmen adaylarının sosyal becerilerinin bu durumdan olumlu etkilendiği göz önüne alındığında, sosyal ă̆ sitelerini kullanmayan öğretmen adayları sosyal ăg sitelerini kullanmaları için teşvik edilmelidir. Ayrıca sosyal ağları kullanmayan öğretmen adaylarının niçin sosyal ağları kullanmadıkları incelenebilir.

- Öğretmen adaylarının sosyal ağ sitelerini kullanma durumları sosyal becerilerini olumlu yönde etkilediğine göre eğitimciler sosyal ağlarda öğrencileri ile arkadaş olmaktan çekinmemelidirler. $\mathrm{Bu}$ ortamlarda öğrencileri ile arkadaşlı kurarak onların sosyal becerilerinin gelişimine katkı sağlamalıdırlar.

- Öğretim elemanları sosyal ăg sitelerini eğitim-öğretim faaliyetlerinde kullanarak öğretmen adaylarına bu konuda yol gösterici bir rol üstlenmelidirler.

- Öğretim elemanları tarafindan sosyal ağ siteleri kullanılarak gerçekleştirilecek bilinçli etkinlikler aracılığ yönde gelişmesine yardımcı olunmalıdır. Bu olumlu gelişme öğrencilerin sosyal beceri düzeylerine de olumlu yansiyacaktır.

- Sosyal ağ sitelerini kullanma durumlarının sosyal becerileri olumlu olarak etkilemesi, sosyal beceri eğitimi ile ilgili etkinliklerde dikkate alınmalıdır.

- Sosyal ağ sitelerini kullanım durumlarının öğretmen adaylarının sosyal becerileri üzerindeki olumlu etkilerini devam ettirebilmek için belirli aralıklarla sosyal ăg sitelerinin etkili kullanımı ile ilgili seminerler düzenlenmelidir. Ayrıca öğretmen adaylarının gerçek yaşamdaki sosyal beceri düzeylerini geliştirmek için sosyal ağ sitelerini kullanmanın yanı sıra dışında spor, sinema, tiyatro gibi etkinliklere de yönlendirilmeleri için gerekli bilgilendirmeler yapılabilir.

Acknowledgement / Bilgilendirme: Bu araştırma ikinci yazarın danışmanlığında, birinci yazarın “ Öğretmen Adaylarinin Sosyal Ağ Sitelerini Kullanma Durumlarina Göre Sosyal Beceri Düzeylerinin İncelenmesi” başlıklı yükseklisans tezinin bir bölümüne dayalı olarak hazırlanmış ve 11.Uluslararası Bilgisayar ve Öğretim Teknolojileri Sempozyumunda özet bildiri olarak sunulmuştur. 


\section{KAYNAKÇA}

Acun, R. (2009). Sosyal ağlar yoluyla katılım kültürü oluşturma: Kaynakça. Info örneği. I. Uluslararası Avrupa Birliği, Demokrasi ve Vatandaşlık Eğitim Sempozyumu, Uşak.

Akınoğlu, O. (2002). Eğitim ve sosyalleşme açısından internet kullanımı (İstanbul örneği). Yayımlanmamış doktora tezi, Sakarya Üniversitesi, Sakarya.

Akkök, F. (2003). Illköğretimde sosyal becerilerin geliştirilmesi, ögrretmen el kitabı. (3. Baskl) İstanbul: Özgür Yayın Dağıtım.

Akt1, S. (2011). Illköğretim sekizinci sinı öğrencilerinin medya okuryazarlı̆̆ ile sosyal beceri düzeyleri arasındaki ilişkinin belirlenmesi. Yayımlanmamış yüksek lisans tezi, Fırat Üniversitesi, Elazı̆̆.

Ateş, A. (2008). Bilgisayar öğretmeni adaylarının uzaktan eğitime yönelik tutumlarının çeşitli değişkenler açısından incelenmesi. Gazi Eğitim Fakültesi Dergisi, 28(3), 125-14.

Bacanl, H. (2008). Sosyal beceri eğitimi (2.Baskl). Ankara: Asal Yayınları.

Balc1, A. (2009). Sosyal bilimlerde araştrma yöntem, teknik ve ilkeler (7.Baskı). Ankara: Pegem Akademi.

Baysal, S. (2010). Siyasal iletişimde bir halkla ilişkiler e-ortamı olarak sosyal ağların kullanımı. Yayımlanmamış doktora tezi, Ege Üniversitesi, İzmir.

Büyüköztürk, Ş., Çakmak, E.K., Akgün, Ö. E., Karadeniz, Ş. ve Demirel, F. (2013). Bilimsel araştırma yöntemleri (3.Baskl). Ankara: Pegem A Yayınc1lı.

Çakır, H. ve Topçu, H. (2005). Bir iletişim dili olarak internet. Erciyes Üniversitesi Sosyal Bilimler Enstitüsü Dergisi, 19, 71-96.

Çetin, E. (2009). Sosyal iletişim ağları ve gençlik: Facebook örneği, I. Uluslararası Davraz Kongresi, Süleyman Demirel Üniversitesi, Isparta.

Deniz, M. (2002). Üniversite öğrencilerinin karar verme stratejileri ve sosyal beceri düzeylerinin tabaskın ben durumları ve bazı özlük niteliklerine göre karşılaştırlmalı olarak incelenmesi. Yayınlanmamış doktora tezi, Selçuk Üniversitesi, Konya.

Field, A. (2009). Discovering statics using SPSS (3rd Ed.). London: SAGE Publications Ltd.

Göker, G., Demir, M. ve Doğan, A. (2010). Ağ Toplumunda sosyalleşme ve paylaşım: Facebook üzerine ampirik bir araştırma. E-Journal of New World Sciences Academy Humanities, 5(2), 183-206.

Gülbahar, Y., Kalelioğlu, F. ve Madran, O. (2010). Sosyal ağların eğitim amaçlı kullanımı. XV. Türkiye'de İnternet Konferansı, İstanbul.

Hark Söylemez, N. (2013). Öğretmen adaylarının sosyal ă̆ sitelerini kullanma durumlarına göre sosyal beceri düzeylerinin incelenmesi. Yayınlanmamış yüksek lisans tezi, Dicle Üniversitesi. Diyarbakır.

Hark Söylemez ve Oral, B. (2017). Öğretmen adaylarının sosyal ağ sitelerini kullanma durumlarına göre sosyal anlatımc1lı beceri düzeylerinin incelenmesi. 11. Uluslararası Bilgisayar ve Ögretim Teknolojileri Sempozyumu, İnönü Üniversitesi, Malatya.

Karasar, N. (2009). Bilimsel araştırma yöntemi (20.baskl). Ankara: Nobel Yayın Dağıtım.

Kobak, K. ve Biçer, S. (2008). Facebook sosyal paylaşım sitesinin kullanım nedenleri. 8th İnternational Education Technology Conference, Anadolu Üniversitesi, Eskişehir.

Özmen,F., C. Aküzüm, C., Sünkür, M. ve Baysal, N. (2011). Sosyal ağ sitelerinin eğitsel ortamlardaki işlevselliği. 6th International Advanced Technologies Symposium (IATS'11), Furat Üniversitesi, Elazığ. 
Pempek, T. A., Yermolayeva, Y. A. ve Calvert, S. L. (2009). College students' social networking experiences on Facebook. Journal of Applied Developmental Psychology, 30(3), 227-238.

Preeti, M. (2009). Use of social networking in a linguistically and culturally rich India. The International Information \& Library Review, 41(3), 129-136.

Sarsar, F. (2008). Çevrimiçi öğrenme ortamlarında işbirlikli ögrenmenin öğretmen adaylarının sosyal becerilerine etkisi. Yayımlanmamış yüksek lisans tezi, Ege Üniversitesi, İzmir.

Seven, S. ve Yoldaş, C. (2007). Sınıf öğretmeni adaylarının sosyal beceri düzeylerinin incelenmesi, Yüzüncü Yll Üniversitesi Eğitim Fakültesi Dergisi, 4(1), 1-18.

Yüksel, G. (2004). Sosyal beceri envanteri el kitabı (1.Baskl). Ankara: Asil Yayın Dağıtım. 